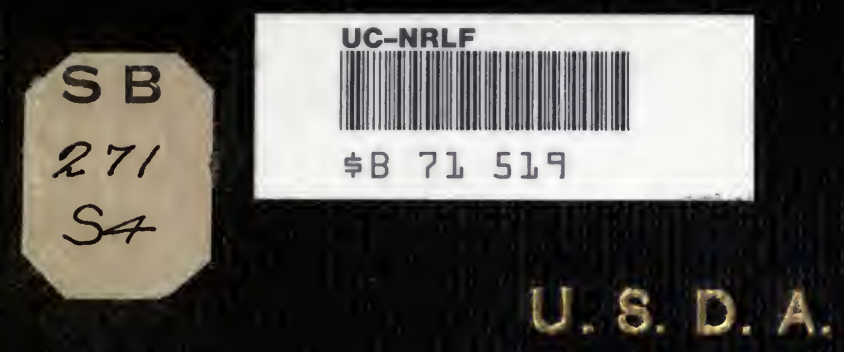

\title{
SPECIAL REPORT ON
}

TEA RAISIMG IN SOUTH CAROLINA

1893
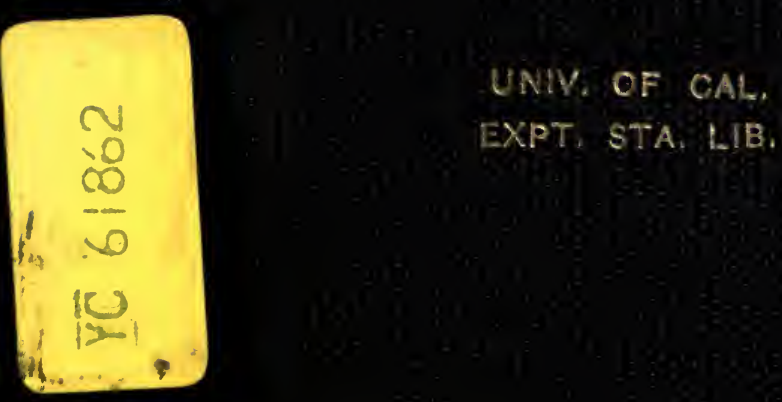


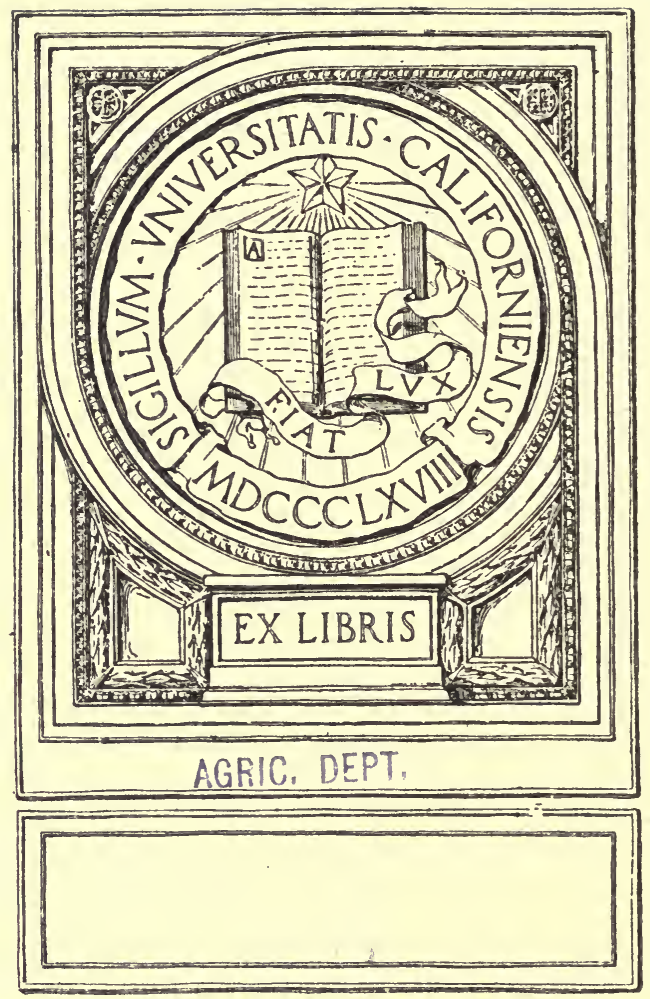






\section{U.S. DEPARTMENT OF AGRICULTURE.}

\section{AGRICULTURA SPECIAL REPORT LIBRARY, \\ UNIVERSITY \\ $\rightarrow$ OF - \\ CALIFORNIA \\ ON}

\section{TEA-RAISING IN SOUTH CAROLINA.}

$\mathrm{BY}$

CHARLES U. SHEPARD, M. D.

FROM THE REPORT OF THE SECRETARY OF AGRICULTURE FOR 1892.

WASHINGTON:

GOVERNHENT PRINTING OFFICE.

1893. 



\section{U.S. DEPARTMENT OF AGRICULTURE.}

\section{SPECIAL REPORT}

\section{TEA-RAISING IN SOUTH CAROLINA.}

BY

CHARLES U. SHEPARD, M. D.

FROM THE REPORT OF THE SECRETARY OF AGRICULTURE FOR 1892.

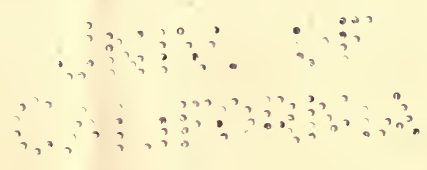

WASHINGTON:

GOVERNMENT PRINTING OFFICE.

1893. 
$5 B 271$
54

Main Lib.

Agric Dept.

AGRIC. DEPT. 


\section{SPECIAL REPORT ON TEA-RAISING IN SOUTH CAROLINA.}

SIR: In compliance with the suggestion of the Assistant Secretary of Agriculture, I have the honor to submit the following report upon experiments in the cultivation of the tea plant at the Pinehurst Experimental Tea Garden, near Summerville, S. C. It embraces, also, certain general observations regarding the varieties grown, yield, profit and loss, and an account of the damage to the plants by the winter of $1892-93$.

Very respectfully,

Hon. J. M. Rusk,

Charles U. Shepard.

Secretary.

\section{TIIE TEA PLANT IN THE UNITED STATES.}

The first tea plant in this section was set out by the French botanist Michaux in 1804, at Middleton Barony, on the Ashley River, and distant some 15 miles from Cliarleston; with it was planted ont the first representative of its cousin, the Camellia juponica. As I saw the former a few years ago, it had grown into a small tree abont 15 feet in height, while of the latter there were many specimens fully twice as tall.

The publications of the U.S. Patent Office and the U.S. Department of Agriculture record the results of many subsequent attempts to inaugurate au American tea industry. Nor is it strange that repeated failure has not checked the ardor of those experimenters who constantly enjoy the realization that their climate is especially favorable for the outdoor cultivation of the Camellia japonica, Azalea indica, and many other subtropical plants, and have read that the Hora of the tea-producing countries of the East finds, to a certain extent, its counterpart here. The little patches and, in some instances, larger gardens which liave resulted from these attempts have prorluced tea of fine flavor, although very generally devoid of that strength of infusion which ap. pears to constitute a most desirable quality for very many drinkers. It may be presumed, however, that this failure in pungency was largely due to defective curing, and especially to inadequate rolling of the leaf, in consequence of which the eup qualities of the tea were not fully developerl. So far as is generally known, it remained for the National Department of Agriculture to begin, about ten years ago, the first serious attempt to produce American commercial tea on a scale sufficiently large to arrive at a decisive result.

The retirement from office of Commissioner William G. Le Due, to whose great interest in this subject the inception of the experiment was due; the death of Mr. John Jackson, under whose experienced manage. 
ment the gardens were established; the great distance of the station fromits souree of management, and the opinion of Commissioner Georg B. Worisg that "the chimatic conditions are not favorable for it" (Report for 1883), eombined to cause the total abandonment by the Government of the gardens which it had established, at great expense, on a portion of the Newington plantation, and only a mile or so distant from Pinehurst farm, which also constituted a part of the same large estate.

The present experimentation owes its undèrtaking to the belief that the previous trials to produce American tea were arrested before reaching definite conclusions; that more careful cultivation and preparation, which might be the result of a lengthier local observation, and the subsequent production of a higher class of teas, might reverse the generally entertained opinion that, as an industry, the cultivation of tea in this country must always prove a failure; and that, if successful, this new field for agricultural enterprise would furnish a wide and comparatively easy outdoor employment for many who are unequal to those rougher operations whose accomplishment under a summer's sun can be borne by but few in this climate.

It needed only the announcement of a revival of tea experiments in this country to excite the liveliest interest in and assistance for the undertaking. The U. S. Department of Agriculture, under the direction of the honorable Secretary, J. M. Rusk, and Assistant Secretary, Edwin Willits, has manifested a deep concern in the project, and has generously borne a very considerable part of the expenditure for procuring consignments of tea seed from far Asia. The Department of State has kindly issued orders to its consuls at the tea ports to obtain these samples, and our foreign representatives have spared no effort to secure the best quality of seed. At our own chief ports and marts the most experienced tea-tasters and merchants have freely given their valuable opinions and advice on the samples of tea which have been submitted to them, and the press has spread over all our wide land whatever reports have appeared concerning the progress made.

It is in deference to this general interest that a report of progress is herewith made, with the intention of limiting its scope to the consideration of the climatic obstacles which have been regarded as insurmountable, and the addition of some of the experience which has been gained during the past few years at Pinehurst. There is an extensive tea literature, but it is not intended to reproduce it here. Those desirous of gaining a general knowledge on the subject are referred to a lecture by Mr. William Saunders, Superintendent of Gardens and Grounds, U. S. Department of Agriculture, delivered before the New York Horticultural Society October 7, 1879, and constituting Special Report No. 18, Department of Agriculture, on "'Tea Culture as a Probable American Industry;" as also to the prize monograph of Col. Edward Money, "The Cultivation and Manufacture of "Tea," 4th edition, 1883, London, W. B. Whittingham \& Co.

\section{REQUISITE CONDITIONS OF THE TEA INDUSTRY.}

The requisite conditions for success in the tea industry are numerous; they embrace sentimental, commercial, and agricultural factors. Under the first belongs the special taste of the people who are to be asked to buy the product. Not only does one country frequently prefer green to black tea, or vice versa, but in the same land different sections demand different sorts or "blends." Any general change in taste is naturally slow. The sentimental factor in deciding whether a tea is to 
its liking is the final judge, so far as the success of any particular sort is concerned. "Do gustibus non est disputandum." Consequently, and firom the outset of the Pinehurst experiments, the representation of all the leading varieties has been sought for, and to-day there are gardens of Japanese, Chinese (including Formosa), and Assam hybrid firom Ceylonese and American seed. That practically all are not represented is due to the great difficulty experienced in procuring sound seed at this great distance from their sources. By carefully adapting to each sort the manufacture most suited to develop its best qualities, it may be possible to offer to a considerable portion of the community its favorite teas, and thus to secure patronage, and, subsequently, profit.

The question of morals does not extend beyond the duty of the Govermment to suppress injurious teas or to expose adulterations. Of the former, excepting the usmally faced green teas, there appear to be very few on the American market.*

A sufficient reason why tea, in a commercial sense, suffers so little arlulteration lies in the cheapness with which it is grown in some countries; there is hardly anything that can be profitably substituted for it without speedy detection. That an immense amount of trashy tea is sold on the American market does not require further comment, that fact being known to all.

The prominent commercial factor is competition from the Asiatic tea comntries, including the price of labor there. A brief consideration shows that the cost of picking tea leaf per pound of the cured tea (it takes about 4 pounds of fresh leaf to make 1 pound of cured tea) hardly exceeds 1 cent in Asia, as against not less than 6 cents here. The difference, 5 cents, constitutes a large part of the gross price which the Asiatic producer receives for his cheaper grades. The long transportation costs only a bagatelle, say 1 to 2 cents per pound, on shipments to Ameriean markets. As the production of American teas must be accomplished at a price which shall permit them to be offered, at our main distributing points, at least on a parity with the same grades of foreign goods, it follows that it is idle to expect to compete with any except the superior foreign teas; but the American grower should realize that with an increase in the price of his product he must diminish the number of possible purchasers. Among the agricultural conditions, none exceerls in importance that of climate; and it will be well to reproduce here the following rather ominous predictions and observations, as they probably constitute the greatest obstacle to our success in the minds of most persons. Col. Money has written:

The elimate required for tea is a hot, damp one. As a rule, a good tea climate is not a healthy one. The rainfall should not be less than 80 to 100 inches per annum, and the more of this that falls in the early part of the year the better. Any climate which, though possessing an abundant rainfall, suffers from dronght in the early part of the year is not, cateris paribus, so good as one where the rain is more equally ciltused. As any drought is prejudicial to tea, it stands to reason hot winds must be very bad. These winds argue great aridity, and the tea plant lnxuriates in eontinnal moisture. 'The less cold weather experienced where tea is the better for the plant. It eau stand and will grow in great cold (freezing point and lower in winter is found in some places where tea is). but I do not think it will ever be grown to a profit on such sites. That tea requires a tenıperate climate was long believed and acted upon by many to their loss. The climate can not be too hot for tea if the heat is aceonpanied with moisture. Tea grown in temperate climates, such as moderate elevations in the Himalayas, is quite different to the tea of hot, moist clinates, such as eastern Bengal. Some people like it better, and certainly the flavor is moredelicate;

* Vide "Foods aud Food Adulterants," Part viI, "Tea, Coffee, and Cocoa Preparations." Bulletin No. 13, Division of Chemistry, U. S. Department of Agriculture. 
but it is very nuch weaker, and the value of Indian tea (in the present state of the home market, where it is principally used for giving "boily" to the washy stuff from China) consists in its strength. Another all important point in fixing on a climate for tea is the fact that, apart from the strength, the yield is double in hot, moist elimes what it is in comparatively dry and temperate ones. A really pleasant climate to live in can not be a good one for tea.

Nevertheless, in describing the various tea districts of India, Col. Money does not hesitate to speak highly of the tea produced in severral of the elevated and more temperate climates, as for example: "The teas produced in Kangra (elevation 3,000 feet) are of a peculiarly delicate flavor, and are consequently highly esteened in the London market." Or again: "Some of the teas (from the Neilgherries, 7,490 feet elevation) have sold very well in the London market, for as regards delicacy of flavor they take a high place." And in reference to the generally elevated Ceylon tea gardens, he remarks: "I believe, take it all in all, Ceylon tea is no better and no worse than Indian teas."

"Tea Cultivation in India" contains the following reference to climate:

Tea, it may be premised, will grow almost anywhere, but not very many elimates will enable it to pay. To describe the best climate in two words, we point confidently to eastern Bengal-a hot, moist elimate, where the thermometer in the shade never exceeds $95^{\circ}$, never falls below $55^{\circ}$; where the rainfall yearly aggregates 100 to 130 inches; where there is never any longdronght, but where rain falls at reasonable intervals all the year round; where heavy dews are frequent; where morning fogs are not uncommon; where the sun shines hot in an atmosphere perfectly free from dust; where at no season ean a breath of hot wind be felt; where light, penetrating rain is more common than furious downpours. Fever and tea go together. It may be a painful fact for tea-planters, but it is no less true. No highly suecessful tea district can ever be a healthy one.

In at least partial controversion of the preceding quotations, Mr. Armstrong has written in "Tea Cultivation in Ceylon," as follows:

The higher the elevation the less rainfall is required, and vice versa. Light showers, alternating with sum, if we could order them so, would give us 1,000 pomnds an acre at 5,000 feet elevation. The higher we go the better our soil must be. I have known many instances of estates up to 3,000 feet giving 400 to 600 ponnds per acre up to 5 years of age; and at 4,000 to 5,000 feet, from 360 to 420 pounds per acre.

It will be noted that these yields of tea are exceptionally good and that the climate at the latter elevation can not be otherwise than temperate.

But granting that the production under the Assamese" climatic conditions is exceedingly favorable, of what transcendent importance is it if the public dislikes the tea? Mr. Samuel Baildon, in "The Tea Industry in India," writes:

Many Indian planters, while finding their teas too strong for their own drinking, have, through insufficiently reasoning the matter out. thought that Indian tea might be drunk alone, and that an injustice was done to the industry in using their teas for fortifying weaker China ones. But as some of the Indian growths are much too strong for use by themselves, and as a large proportion of the China tea imports into England require strengthening, these strong growths from India-which can not, be used alone-are valuable for giving strength to inferior Chinese teas, and for this reason only. Indian teas of unpalatable strength predominate over those of medim strength. Planters wliose only experience of Indian tea has been obtained in Assam, or districts where the strongest kinds are grown, have no idea of the really fine, delicately flarored teas that are sent to England from other districts-teas that undoubtedly are well snite:l for drinking alone. I well know the regular eries about Indian teas being far more economiral than Chinese ones, and I believe in and arlvocato the practice whenever I can, but only as applicit to Neilgherry, Kangra Valley, or finer Darjeeling teas. Some of the produce from these districts is delicious and possesses a delicacy of flavor which can not be compared with anything coming from Assam.

The accompanying table exhibits the mean monthly temperature and rainfall, together with other interesting data, of the climates of several 
of the most important Indian tea provinees; of Charleston, S. C.; and of some Chinese and Japanese stations. It is interesting to compare the Indian and Japanese temperatures and rainfall with those of Charles. ton. There is obviously much more difference in the annual precipitation of moisture than in the mean annual temperature. The mean annual temperature of Summerville, on whose ontskirts Pinehurst farm is situated, is $65 \frac{1}{4}$ for the past sixteen years. It is hoped to ultimately establish a simple meteorological station here. The maximum temper. ature of $104^{\circ}$ (July 12, 1879) and minimum of $10^{\circ}$ (January 11, 1886) have constituted the extremes for twenty-one years at Charleston; the average date of the latest frost, March 21, and of the earliest frost, November 5, also for the same period. Neither, in regard to these observations, would there be much difference between Charleston and Summerville.

Comparison of climate of Charleston, S. C., with some Asiatic tea climates.

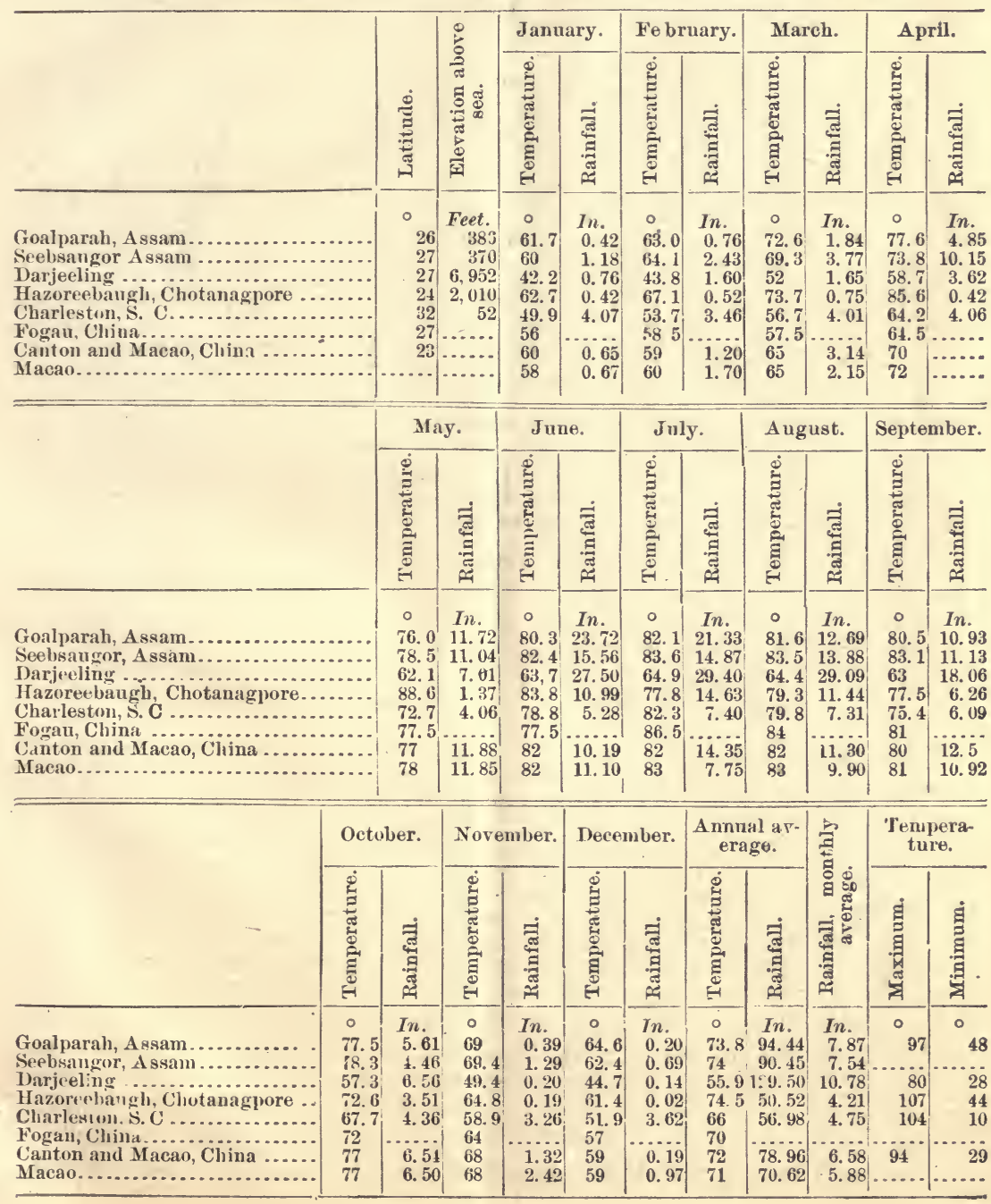


Average temperature.

\begin{tabular}{|c|c|c|c|c|c|}
\hline . & Winter. & Spring. & $\begin{array}{l}\text { Sum- } \\
\text { ner. }\end{array}$ & $\underset{\text { tumn. }}{\mathbf{A u} \cdot}$ & $\begin{array}{l}\text { Whole } \\
\text { year. }\end{array}$ \\
\hline 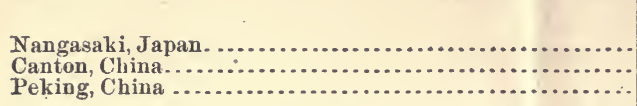 & $\begin{array}{l}\circ \\
46 \\
58 \\
26.42\end{array}$ & $\begin{array}{l}\circ \\
59 \\
71 \\
56.30\end{array}$ & $\begin{array}{l}\circ \\
81 \\
83 \\
82.58\end{array}$ & $\begin{array}{l}\circ \\
70 \\
75 \\
54.32\end{array}$ & $\begin{array}{l}\circ \\
63 \\
71.7 \\
54.09\end{array}$ \\
\hline
\end{tabular}

In regard to the climate of the Chinese tea-producing provinces, $\mathrm{Mr}$. Samuel Ball has afforded the following information in "The Cultivation and Manufacture of Tea in China:"

The quantity of rain which falls at Canton and Macao during the southwest monsoon (May to October), when the winds come charged with moisture from the sea, amounts to 67.85 inches, whereas during the northeast monsoon (November to April), when the wind blows over the laud, there falls 11.11 inches; thus making the total quantity 78.96 inches. But the annual quantity which fills at Peking is only 27.98 inehes. Hence it appears that the sontherly winds, in their passage over this extensive Empire, deposit the moistnre with which they are saturated gradually and less copiously as they advance to the north, till finally both one and the other become exhausted as they reach Peking. * * * In the center of these two extremes, Peking and Canton, and between the latitude $23^{\circ}$ and $33^{\circ}$ north, the tea plant was found indigenous at a remote period of the Chinese history. This comprises the central as well as the most populous and flonrishing provinces of the Enpire, and includes that part most suitable to its grow th, and where it is found to flourish in the present day. In this division of the conntry between north latitude $27^{\circ}$ and $31^{\circ}$ are also situated the distriets connected. with the foreign trale, whence the greater part of the tea most esteemed by the Chinese is also procured for their home consiumption.

In the green-tea country, situated in the district of Wheychew-fu, north latitude $29^{\circ} 58^{\prime} 30^{\prime \prime}$, from December until March the weather continues cold ; frost frequently prevails, and snow oceasionally; water freezes in the house. In July the summer regularly sets in, and the intensity of the heat is equal to that of Canton.

The Bohea (black tea)' conntry, in Fokien, differs little from the Hyson distriets in point of temperature. The tea men deseribe the cold as less severe, and the fall of snow, as well as the thickness of the ice as somewhat less. * * * At Amoy (latitude $24^{\circ} 27^{\prime} 36^{\prime \prime}$ ), which is a tea distriet prodneing teas suitable to the foreign markets, and some of very delicate flavor, the temperature seems hardly to vary from that of Canton. Annual mean temperature was $69.7^{\circ}$, the lowest temperature marked being $49^{\circ}$ and the highest $90^{\circ}$.

The preceding remarks are suffieient to show that severe frost and occasional snow prevail in the tea districts, and on some oceasions, thongh rare, so late as the verual equinox. Yet there is reason to believe, on average of seasons, that the frost is not very intense or of long duration.

\section{CLIMATIC REQUIREMEN'TS.}

We may, therefore, assume that a deficiency in one of the conditions usually insisted upon as being requisite for successful tea cultivation, viz, an equable and rather elevated temperature and somewhat excessive rainfall, does not preclude the establishment of that industry on a safe foundation. It is probable that the strength of tea may be considerably impaired by a material deviation in what is regarded as the normal climate; it may not serve to fortify weak teas, but there is ground for hope that it may ocenpy an independent position, at least in a country where the strongest teas are not relished and where a delicate flavor is highly appreciated by a sufficiently large class to war. rant the fullest deterence to its demands. So far as concerns any American tea that is likely to be produced during the next generation or two, there will be no occasion to look beyond our own markets, and at present they are almost wholly supplied from China and Japan. If, therefore, it be contemplated to cater to the American taste, it must 


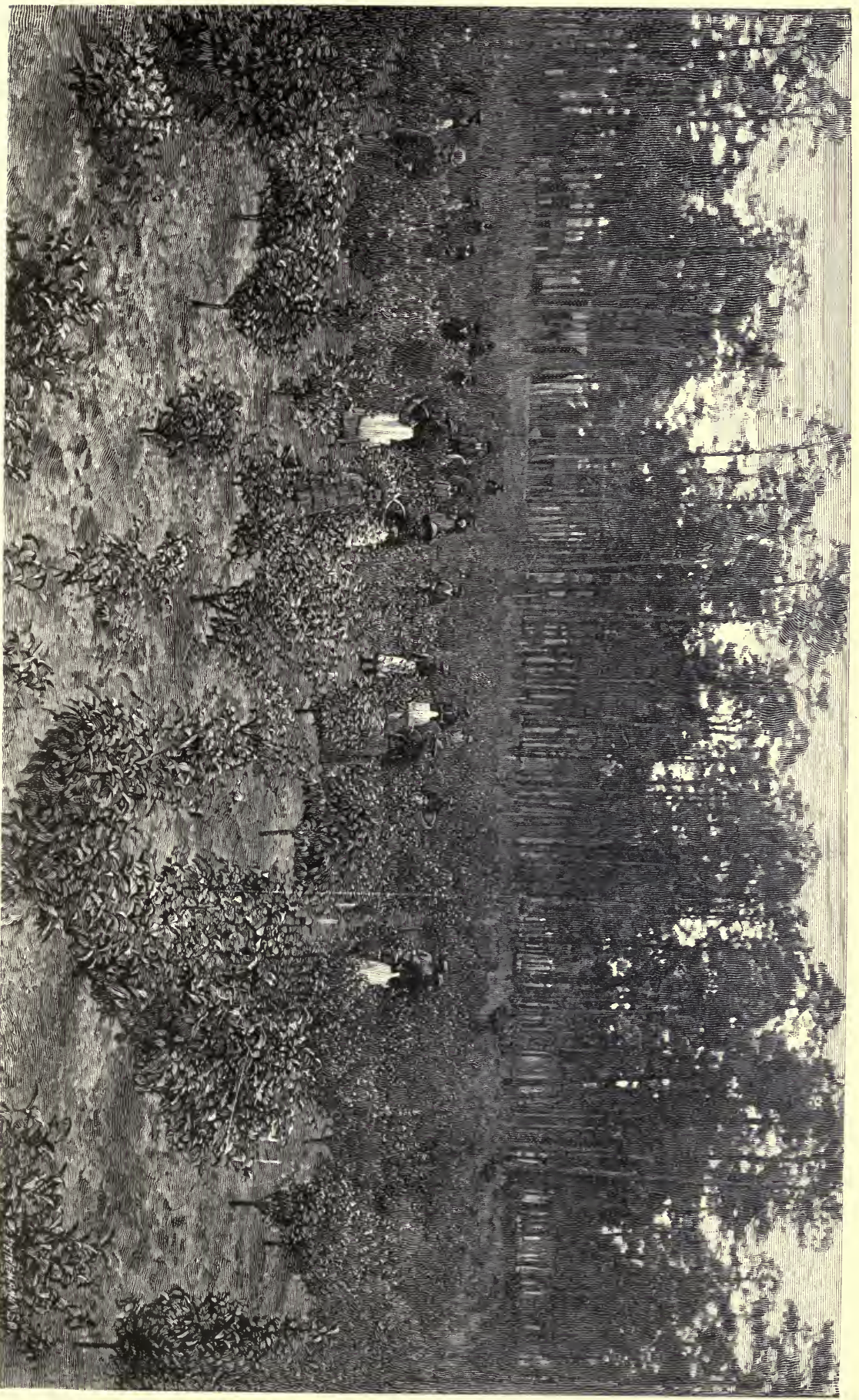





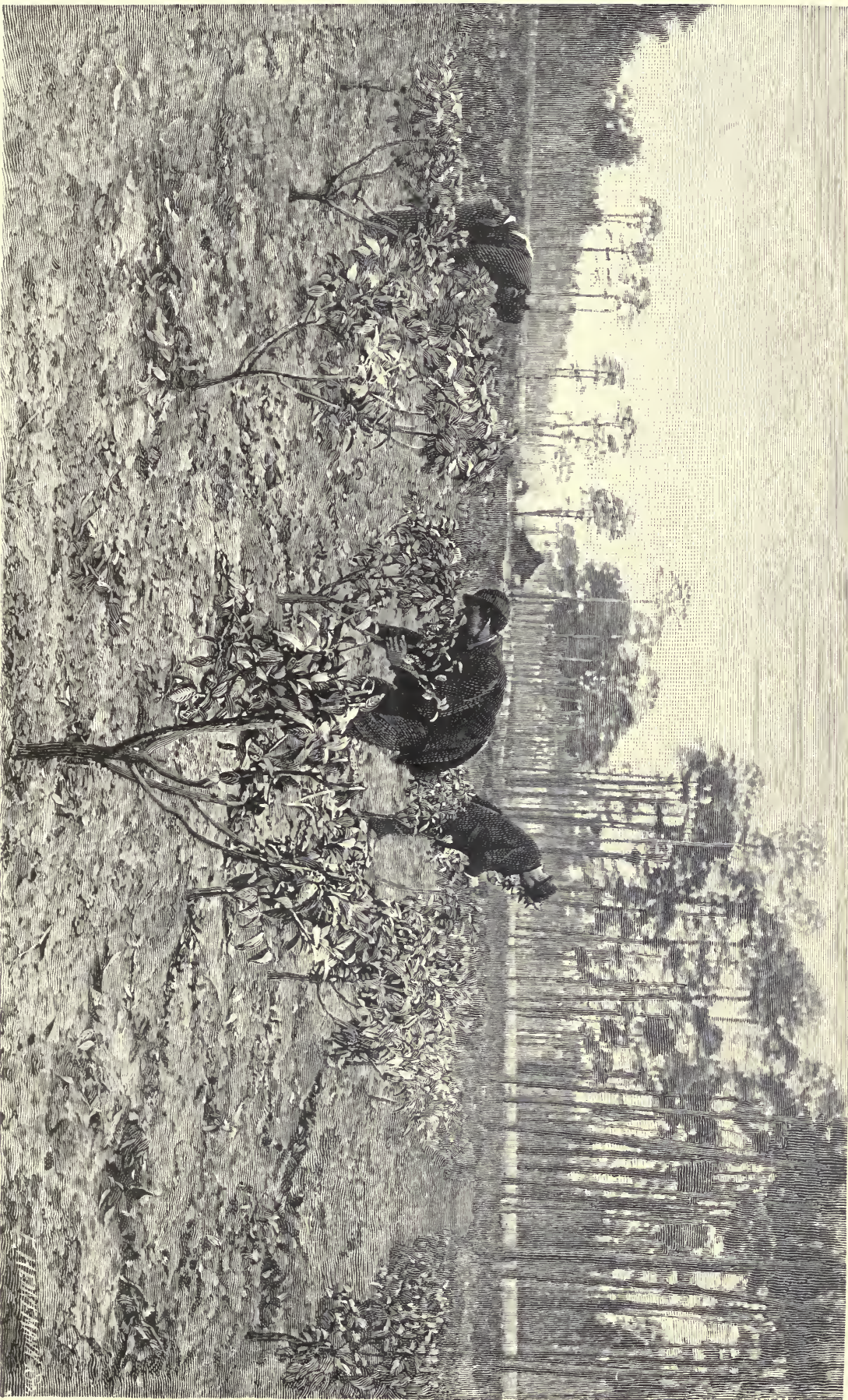





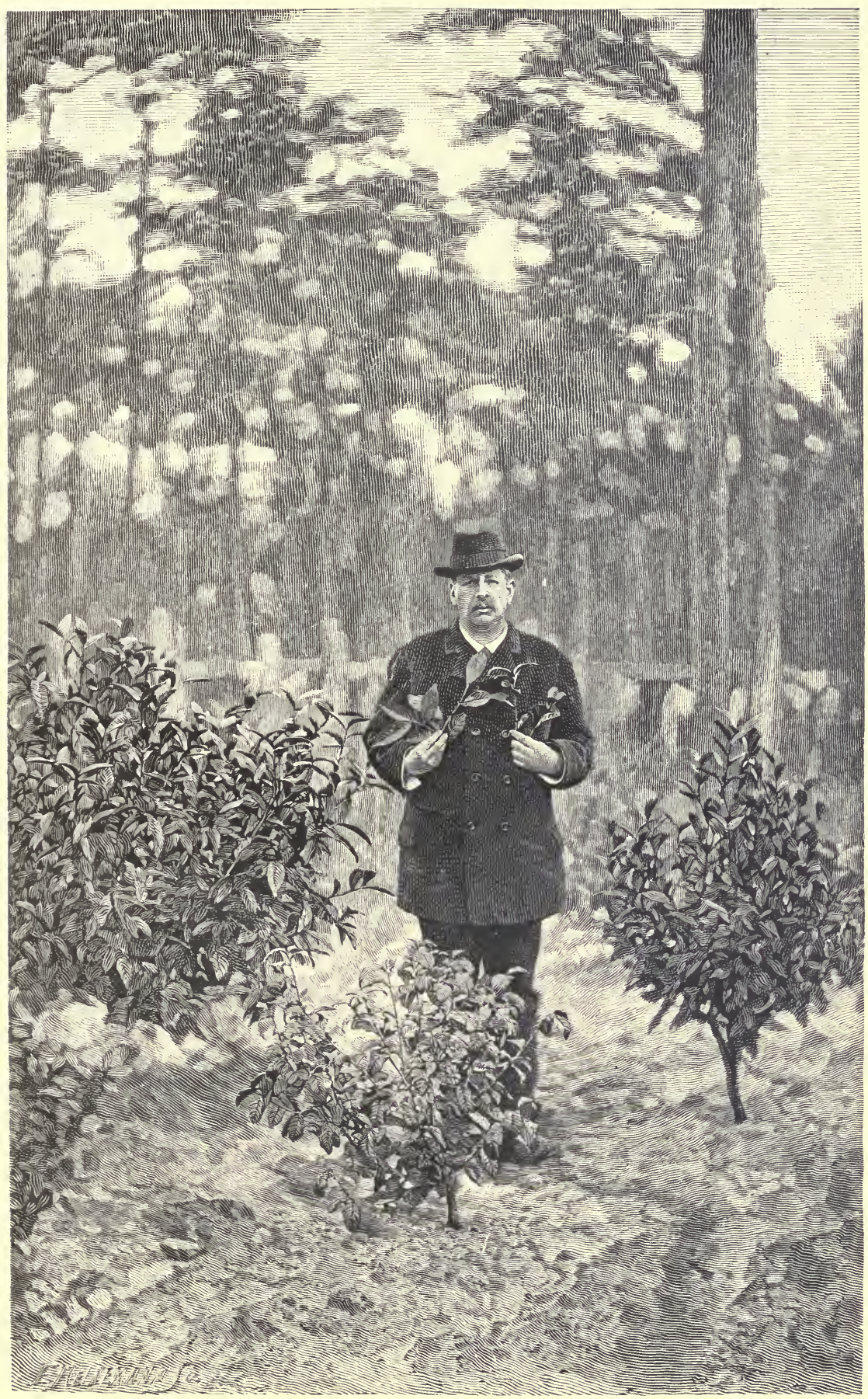

assam hybrid Tea Plants at Pinehurst, Three and a half Years Old and less, SHOWING VARIATION IN Size of Leaf and General Vigor OF GROWTH. 

surely prove more remunerative to manufacture an article similar to those in use here, rather than to imitate (even if it were possible) the more pungent Indian teas, which at present are only slightly imported. It is said that the tea from Formosa commands the highest price in this country, but some fine grades from Ceylon and India find a high price in rather limited quantities, the former being generally preferred.

It should not be understood that the attempt to produce strong as well as delicate teas has been abandoned at these gardens. The best writers on tea concede that delicacy of flavor and strong raspiness do not go together. The ideal beverage should possess both strength and flavor, as may be attained by picking only the youngest and tenderest leaves and a generous application of manure.

The idea that a colder climate than the Bengalese plains (it being immaterial whether the result of a greater elevation or a higher latitude), and one that may be regarded at least as healthy, is not suited to the production of the largest crops of superior teas, seems to have been refuted by the experience of the mountain gardens of Ceylon; but special stress is laid, in this case, on the richness of the soil as compensating for the deficiency in temperature. That ordinarily severe cold, as evidenced by ice and snow, seriously curtails the annual yield there can be no doubt, be it from the shortness of the growing season or the too intense hibernation of the plants; nor is it probable that the most generous cultivation can atone for an extreme winter. It is to be regretted that further meteorological data are not at hand. Nevertheless it may be urged that the citations given above afford a reasonable basis for the hope-which is the corner-stone of our undertakingthat the climate of this section does not necessarily proseribe success in establishing a successful tea industry here. 'It is anticipated that natural deficiency in some directions must be counterbalanced by extraordiuary artificial stimulation in others. But it ought not to be regarded as stranger, should ultimate success crown our efforts, that musual care and attention can compel the remumerative cultivation of tea outside of its natural zone any more than in the case of tobacco and many other crops.

\section{QUALITY OF THE TEA PRODUCFD.}

This past summer some of the Pinehurst plants were sufficiently advanced to warrant picking the leaf. The great majority of them had been raised from seed in 1889, and set ont that autumn. A limited number were a few months older. They belong to the "Assam hybrid" variety, $i . e$. , the cross between the Assamese and Chinese sorts, and came from stock that had been thoroughly acclimated by probably thirty years' growth in this comntry. The plants had been systematically "topped" with garlen shears and afterwards carefully prumed with a knife during the winter of 1891-92, and throughout their growth had been carefully cultivated and generously manured. (Plates I-III.) They covered small areas on various soils, viz, underdrained pond and high swamp, the slope of a clay hill, and a flat, sandy pine land. So free had been the artificial enrichment of all of these plats that no material differences in the quality or quantity of yield were observed. It was designed to test by these first experiments whether commercial tea could be raised at all. Below are given the results from picking and curing such leat as appeared to be suitable for manufacture, and might be spared without impairing the subsequent luxuriant development of the plants.

A proper regard for the space that can be allowed this article neces- 
sarily limits the publication of the reports which have been received firom thiose who have tested the Pinehurst tea of 1892. As the Assam hybrid leaf is better adapted for the manufacture of black $(i$. e., fermented) tea, that mode of preparation was followed. It is not claimed that all the responses were equally enthusiastic, but all were favorable. Some of the experts, as might have been expected, did not hesitate to express the doubt whether the Pinehurst teas wonld find favor in their sections of country. But we shall be pardoned if only the more flattering testimonials are published, especially as it is our object to demonstrate that superior teas may be grown here.

(1) Letter from Hon. Edwin Willits, Assistant Secretary of Agriculture, dated November 2, 1892:

I wish to say that we are very much pleased with the samples. Not only this, but we sent a sample to the traveling agent of a large tea firm in Detroit for his judgment, advising him as to where the tea was produced. He took the tea to the store, and without giving them any information with regard to the same, it was tested by two of the leading members of the firm, each making a separate test. They pronoinced it very excellent English breakfast tea, and, as I recollect, claimed that it was better than any breakfast tea they had in the store, or at least equally good; and when the information was given them as to the place of production they were very much surprised and wished to know if any considerable amount could be purchased.

(2) Letter from Mr. N. W. Burchell, of Washington, D. C., under date of July 16, 1892:

The No. 2 tea is the best American tea I ever saw, and wonld bring at wholesale a good price. If sold as American tea, and thereby creating a sentiment for a season or so, it would bring more than the same high grade of India tea.

(3) Opinion of Mr. Gillet Gill, of Martin Gillet \& Co., the celebrated tea merchants of Baltimore, Md., as published in the Sun, of that city, and other papers:

The first marketable tea ever produced in the United States was brought to Baltimore to-day by Charles U. Shepard, of Summerville, S. C., who grew and cured the plant on his farm. The American tea was tested by Mr. Gillet Gill, who pronounced it equal to the best high-grade English breakfast tea and supcrior to many grades that come from India and China. The samples brought here by Mr. Shepard are all of one quality and character-black, crisp, and well scented. It makes a strong beverage. This quality of the American tea is said by Mr. Gill to be due solely to its treatment in fermentation and curing. Other methods of curing the American product will produce tea similar to the several brands that come from India and Clina. Judging from Mr. Shepard's samples, Mr. Giil says he believes the successful growing of tea in the United States is established, and that the industry should be encouraged aud fostered.

(4) Opinion of Mr. Charles Kerr Reid, tea expert and merchant, of Philadelphia:

Picking of June 14, season of 1892. Report on samples from the four grades into which the tea was sifted:

No. 1. Rather handsome, rather small, even blackish leaf with Pekoe flower. Strictly extra fine tea; strong, full, and rich South Carolina Pekoe flavor. Value, 32 to 35 cents wholesale.

No. 2. Blackish, even leaf, with a few Pekoe tips. Fine to extra fine tea; strong, brisk Soutli Carolina Souchong Pekoe flavor. Value, 25 to 30 cents wholesale.

No. 3. Rather bold, evenish, curled black leaf; mirldling tea (or preferred), strong, brisk, fresh-burnt South Carolina Sonchong flavor. Value, 22 to 25 cents wholesale.

No. 4. Bold, black, uneven curly-leaf middling tea; rather strong, fresh-burnt Sonth Carolina Souchong flavor. Value, 20 to 21 cents wholesale.

The retail prices are generally more than double the wholesale on the finer grades, and from 50 to 100 per cent higher on the lower qualities. Mr. Reid has kinclly added the following remarks:

Your teas I find have an individual, distinct, and pronounced character, different from the teas of any other country, consequently, I describe their character flavor 
as "South Carolina flavor." They have merit and intrinsic value of a high order. I have very much pleasure in offering you my sincero congratulations on the complete success of your enterprise in having produced from the soil of the United States of America the commercial article "tea leaf," equal in style and value and on a par with the fine teas of the world.

(5) Concerning the best of these samples, and after submitting it to a thorough trial, a friend in New York, who was formerly and largely interested in the tea trade, has written:

It is good original stock aud is unusnally well prepared; has all the characteristies of an Indian or Ceylon tea, and is particularly brisk or toasty in firing, which is desirable. I am inclined to believe that it is better tea than Tettley's, which is sold in dry gools stores at 50 cents for a half-pound package; that would make the original value before packed somewhere abont 35 cents per pound.

The same authority subsequently wrote in reference to some similar teas of a later manufacture:

The sample B, as well as the sample which I valued in New York at 38 cents, interested inc. Yonrs is not a slowy tea, but has the "solid merit," holding its tine quality in taste as it becomes cold; it is what we would call a "deceptive tea" to the tea-tasters, not to the consumers, and if the consumer were once accustomed to it, he would think other teas trash, which the tea-taster might have called "only a trifle poorer."

Based on Mr. Reid's valuations, 100 pounds of Pinehurst tea, divided into classes by sifting, should have the following valuation, viz:

\begin{tabular}{|c|c|c|c|}
\hline & \multirow[b]{2}{*}{ Yield. } & \multicolumn{2}{|c|}{ Value. } \\
\hline & & $\begin{array}{l}\text { Whole- } \\
\text { sale. }\end{array}$ & Retail. \\
\hline 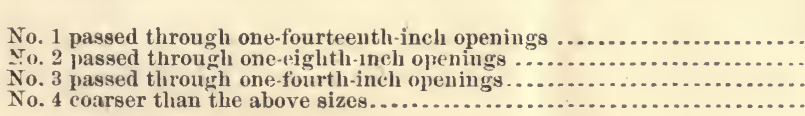 & $\begin{array}{r}\text { Pounds. } \\
16.00 \\
30.00 \\
52.50 \\
1.50\end{array}$ & $\begin{array}{r}\$ 5.36 \\
8.25 \\
12.34 \\
.30\end{array}$ & $\begin{array}{r}\$ 10.80 \\
16.50 \\
19.19 \\
.49\end{array}$ \\
\hline Total $\ldots \ldots \ldots \ldots \ldots \ldots \ldots \ldots \ldots$ & 100.00 & 28.25 & 46.98 \\
\hline
\end{tabular}

The result, then, of sorting by size of finished leaf is to obtain a bulk valuation of $28 \frac{1}{4}$ cents per pound, or 47 cents retail price in the larger cities; in the country, the latter price would be from 60 cents upward.

As an interesting fact may be mentioned that the picking of August 22,1892 , was prepared as a whole-that is, without division by sifting. Concerning it Mr. Reid reported, "Rather bold, rather uneven, curly black leaf, with bloom and Pekoe flower. Fine tea, rather rich, strong, brisk, malty, Pekoe touch and flavor. Wholesale value in this market in bulk, 30 to 32 cents; retail value in the same, about 60 cents."

Very truly has Col. Money remarked, in referring to the teas made by Mr. Jackson in this country, "No reason why the teas should not be good;" and we hope later on to successfinly combat his further suggestion, " but the labor difficulty will, I think, prevent tea paying there."

\section{YIELD OF TEA.}

Col. Money gives the following estimate of the probable yield per acre on flat land, good soil, in a good tea climate, and with hybrid plants, if really high cultivation and liberal manuring is carried out: 


\begin{tabular}{|c|c|c|c|}
\hline Year. & $\begin{array}{c}\text { Tea per } \\
\text { acre. }\end{array}$ & Year. & $\begin{array}{l}\text { Tea pex } \\
\text { acre. }\end{array}$ \\
\hline First .. & Pounds. & Sixth ......... & $\begin{array}{r}\text { Pounds } \\
400\end{array}$ \\
\hline 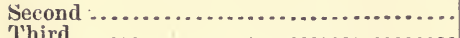 & $\begin{array}{r}0 \\
40\end{array}$ & $\begin{array}{l}\text { Seventh } \ldots \ldots \ldots \ldots \ldots \ldots \ldots \ldots \ldots \ldots \ldots \ldots \\
\text { Eighith }\end{array}$ & $\begin{array}{l}480 \\
560\end{array}$ \\
\hline $\begin{array}{l}\text { Third } \\
\text { Fourth } \ldots \ldots\end{array}$ & $\begin{array}{r}40 \\
160\end{array}$ & $\begin{array}{l}\text { Ninth } \\
\text { Nint }\end{array}$ & 600 \\
\hline Fifth ....................................... & 320 & 'Tenth ..................................... & 640 \\
\hline
\end{tabular}

The Pinehurst plants had been set out at greater distance than is the practice in the. East, with the object of substituting cultivators and plows drawn by mules for hand labor and the spade. After making due allowance for this difference and for average vacancies (where plants have died), and thus estimating the production by the same number of plants, we find the average yield of the Pinehurst gardens for the past season to have reached about $37 \frac{1}{2}$ pounds of (cured) tea per acre. Of the earlier "flushes" (as the successive crop)s of young and tender leaf are ealled), purposely very little was picked; of the midsum. mer ones we were careful to confine the picking to the smallest leaf, and in the antumu at least one abundant flush was permitted to remain on the bushes. In other words, the standard production as laid down by Col. Money might readily have been attained. Indeed, in view of subsequent events, it would have been better to have picked the late (October) flush, as probably thereby we might have prevented the florescence of the plants, with all of its attendant drain on their resources, and the subsequent entailed cost of picking off the iucipient seed in order to prevent the yet further exhaustion of the bushes by its full development through the next season. But we will assume that the Indian grower exercises as much care with his own gardens, and we'will rest our case on the actual figures submitted.

The results at Pinehurst are all the more gratifying as they were obtained on plants exhibiting great difference in form and luxuriance of growth and in flushing. The seed from which they sprang had been brought firm India long before the inanguration of the recent successful attempt to raise the grades of those teas by a judicious selection of seed and most careful cultivation. From the gardens now being established at Pinehurst, and in consequence of the great care bestowed on their composition, it is hoped to obtain much finer teas in the future.

The results obtained at Pinehurst during the past summer are certainly gratifying, and yet the partial suecess already achieved carries with it great anxiety as to the future. The summer of 1892 was specially favorable for the growth of tea, and the bushes made great strides under the influence of abundant rain in the picking season. The rainfall was as follows for that period, viz: May, 3.03 inches; Jume, 10.32 inches; July, 10.33 inches; Angust, 4.73 inches; September, to. 28th, 11.77 inches; for picking season, 40 inches. The meteorological statisties for this region do not extend the hope of the frequent repetition of such weather. Then, again, who ean tell how soon some detrimental or even fatal blight may attack our gardens? This does not appear probable; but the red spider or some other wretched enemy may suddenly swoop down and create great destruction. For the present, the plan is to develop the utmost luxuriance of growth on the part of the better plants and to extirpate all feeble bushes.

PROFIT OR LOSS.

It is as yet too early in our experimeutation to exhibit calculations as to the cost of productiou. Our gardens are small (altogether not 
exceeding 12 acres), and nnder no circumstances capable of bearing the "fixed charges," which with little advance might apply to a much larger acreage. For the immediate future there is no necessity of erecting and conducting a regular factory such as may be found on almost all Indian and Ceylonese plantations; although it would be desirable to impart to all tea the uniformity of preparation which the perfected machinery of to-dey affords. With the substitution of steam machinery for haud labor and the attendant economy, and an enlargement of the gardens to warrant such outlay, the difference between the actual cost of Asiatic and American teas would be reduced to those manual operations in the field where it is impossible to replace hand labor by machines. Nor has the public had, as yet, an opportunity of forming an opinion on the merits of American tea, and as an industry it must rely on the patronage of our people.

It is, however, natural to presume that some "ciphering" on the question of profit has been indulged in. With some misgivings, but nevertheless that this article may not be incomplete in this respect, we submit the following (hoped-for) estimate of the expense involved in raising and curing a pound of tea in this section, if the future results corroborate those of the past. The following quotation is taken from an article recently prepared for "American Gardening:"

Estimated cost of tea to be produced at Pinehurst, when the gardens shall produce at the rate of 400 to 500 pounds per acre and per annum, and after the introduction of machinery, whenever it is possible to substitute it for manual labor:

Picking leaf Cents.

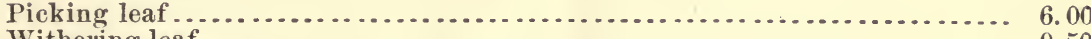

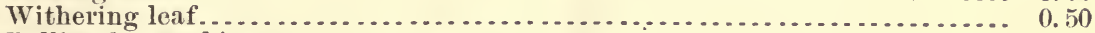

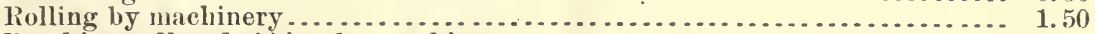

Breaking roll and sifting by machinery . . . . . . . . . . . . . . . . . . . . . . 0.50

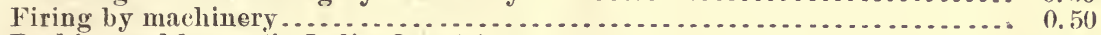

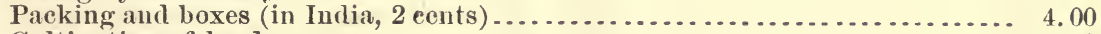

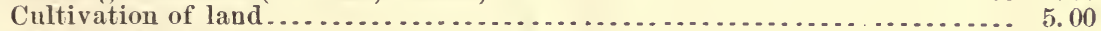

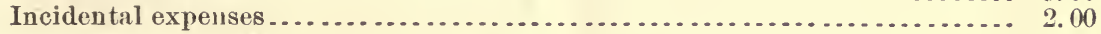

Cost per pound of (cured) tea .............................. 20. 00

This estimate does not include the proper fixed charges, which must amount to a large sum by the end of the sixth year after plauting a garden, when under favorable conditions the outlook should equal 400 pounds of (cured) tea.

The reader must decide whether this exposition of the present outlook of the Pinehurst farm is sufficiently encouraging to warrant the rather roseate predictions that its friends have indulged in; as also whether there is justifiable ground for anticipating the successful establishment of an American tea industry.

The U. S. Department of A griculture has kindly consented to place on exhibition at the World's Columbian Exposition some of the Pinehurst teas.

\section{EFFECT OF INTENSE COLD ON TEA PLANT.}

Beginning with the 27th of December, 1892, and terminating January 22,1893 , an exceptionally long period of intense cold prevailed in the South Atlantic States and produced a marked effect on the local tea gardens. Although considerable injury followed this cold wave, it was well that this severe test should have been encountered thus early in the experiment, especially if the proper lessons can be drawn from the unusual experience.

Mr. L. N. Jesunofsky, observer in the Weather Bureau at Charleston, has very kindly prepared the accompanying table, which demonstrates 
in a very lucid manner the exeeptional duration of this winter's cold. The table permits the following important deductions:

December, 1992. - The mean of three consecutive coldest days was $27^{\circ}$ F.; lower than any record for the same month.

The numlier of days with a mean daily temperature below $32^{\circ} \mathrm{F}$. was 2 , only equaled in 1872. The minimum temperature, $25^{\circ}$ F., was surpassed only in 1876 (23 $\mathrm{F}$. ) and $1880\left(13^{\circ} \mathrm{F}.\right)$. The number of days with minimum temperature below $32^{\circ}$ F. was 5 ; only surpassed in 1872 ( 7 days), 1876 (10 days), and 1880 (6 days).

January, 1893. - The mean of three consecutive coldest days was 24 F., only surpassed in 1886 (20 F.). 'I'he number of days with a mean daily temperature below $320 \mathrm{~F}$. was 5, surpassed only once in 1886 (6 days). The minimum temperature, $20^{\circ}$

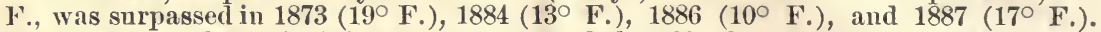
The number of days of mininum temperature below $32^{\circ} \mathbf{F}$. was 13 , which is far beyond any previous record.

The mean temperature for Jauuary for twenty-three years was.............

T'le mean temperature for January, 1886 , was . . . . . . . . . . . . . . . . . . .

The mean temperature for January, $18 ! 13$, was . . . . . . . . . . . . . . . . . . .

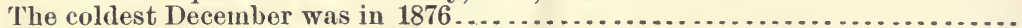

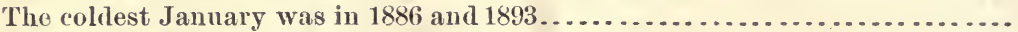

The coldest February was in 1886.

January, 1886, was regarded as the coldest weather experienced for fifty years.

If the weather for thirty days from December 27, 1892 (inclusive), be compared with any of the above records, it will be seen that its mean temperature is $39.8^{\circ} \mathrm{F}^{*}{ }^{*}$ Thus there is ample ground for believing that the duration of extremely cold weather in the winter of 1892-93 was larger than any year of which there are records.

The cold was much more severe at Pinehurst than in Charleston, as the following notes show:

The week following Christmas was very cold, so that mueh iee was formed and the ground frozen to the deptlo of about an inch for several mornings, although in the afteruoon it generally thawed ont. The week January 8 to 15 was also cold, so that all pruning was abandoned for the time being. But the week Jannary 15 to January 22 has been unusually severe, as the following observations show : Saturday, January $14,17^{\circ}$ F. at 8 a. m.; Monday, January $16,20^{\circ}$ F. at 8 a. m.; Tuesday, Jannary $17,14^{\circ} \mathrm{F}$. at 7 a. m.; Wednesday, Jaunary $18,18^{\circ} \mathrm{F}$, at $7 \mathrm{a} . \mathrm{m}$. On the 18 th $2 \frac{1}{2}$ inclies of snow fell in the forenoon, followed by sleet in the afternoon, and the whole was frozen in the early night. Thursday forenoon all vegetation was covered with ice, and of such weight as to cause great destruction among the largest trees (yellow pine and oaks) of this region.

Freezing weather continued steadily until Friday afternoon, when a slight thaw occurred. Ice covered all the tea bushes until Saturday afternoon, and those in a sheltered position until Sunday, the 22d, at midday. 'The cold weather continued with frozen ground every morning until Wednesday, January 25. The depth of frost in the ground rarely exceeded 2 inclies.

The effect of the prolonged cold upon the tea gardens has sufficiently developed since the return of the usual winter weather and the occurrence of several showers, so that now it may be possible to judge of the injury inflicted.

Quite young plantations have suffered considerably by the loss of their tenderest leaves; but they will probably recover almost entirely, with the exception of one garden of very tender and young Ceylon plants, which have been very generally killed to the ground. These last may spring up again from the roots. Nevertheless enough of these plants have survived the trial to furnish abundant material for propagation by cuttings another autumn, so that there shall be a garden devoted to the most hardy of this tender and valuable variety. Partly from a belief that the location of the Ceylon tea garden was unusually exposed and partly from our confidence that by a judicious mulching

* This is half a degree lower than the mean temperature of the thirty days (January 9 to February 8, inclusive), eovering the phenomenal cold of 1886. 


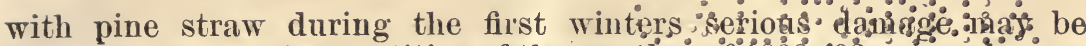
averted, even on the repetition of the weather of $1892-93$, several acres are now being planted with the best Ceylon tea seed.

Other seedings and young plants, particularly in exposed situations, have not infrequently lost their top foliage; but the loss is inconsiderable, although involving the retardation of their development.

Among the larger and older plants the injury from the cold weather shows itself in two directions, viz, a splitting of the bark of the trunk, whereby the latter becomes denuded and the plant dies. This form of damage has happened to not exceeding 1 or 2 per cent, but the plants thus affected were (as might be expected) among the thriftiest and finest in the tea gardens. The other injury was the loss of the youngest leaves and twigs on plants of apparently greater susceptibility. But it does not seem to involve further destruction, except in comparatively few eases. Very careful examination of the older gardens shows that the total loss from cold during the past winter is decidedly less than 5 per cent of the total plants.

The location and drainage of the tea gardens are of the first importance in climates where there is liability to such extreme cold. Even tender Assam survived the experience of this winter where sheltered by trees from the wind and on a dry hill. It may be well to avoid encouraging by autumnal manuring the growth of plants during the winter where it is apt to be cold.

TABLE 1.-Showing frequency of prolonged periods of low temperature at Charleston, $S$. C., for January, February, and December, 1871, to date (January, 1893), inclusive.

[Furnished for C. U. Shepard, M. D., Summerville, S. C.]

\begin{tabular}{|c|c|c|c|c|c|c|c|c|c|c|c|c|}
\hline \multirow[b]{2}{*}{ Year. } & \multicolumn{4}{|c|}{ January. } & \multicolumn{4}{|c|}{ Felruary. } & \multicolumn{4}{|c|}{ December. } \\
\hline & 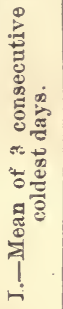 & 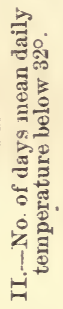 & 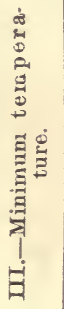 & 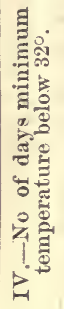 & 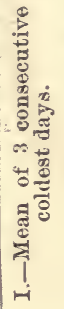 & 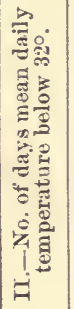 & 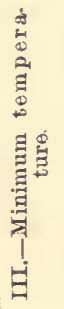 & 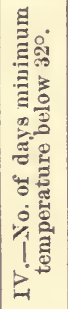 & 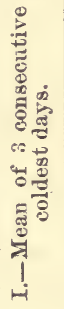 & 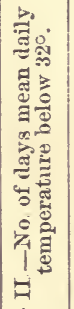 & 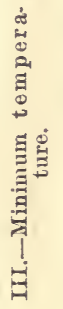 & 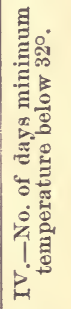 \\
\hline & 0 & Daus. & 0 & Davs. & & Days. & & Daya. & o & $D_{\subset} \boldsymbol{x} \boldsymbol{s}$ & & \\
\hline 871. & 42 & 0 & 28 & -2 & 47 & & 36 & & 38 & & 26 . & \\
\hline & 35 & 0 & 25 & 5 & 40 & 0 & 30 & 3 & 33 & 2 & 25 & \\
\hline & 35 & & 19 & 5 & 45 & 0 & 33 & 0 & 41 & 0 & 27 & \\
\hline 874 & 46 & & 29 & 2 & 44 & 0 & 36 & 0 & 47 & 0 & 33 & \\
\hline & 39 & 0 & 30 & 5 & 38 & 0 & 28 & 5 & 43 & 0 & 25 & 1 \\
\hline & 39 & 0 & 28 & 1 & 43 & 0 & 31 & 1 & 33 & 1 & 23 & 10 \\
\hline & 36 & 0 & 26 & 5 & 44 & 0 & 35 & 0 & 43 & 0 & 33 & \\
\hline & 38 & 0 & 30 & 3 & 44 & 0 & 32 & 0 & 38 & 0 & 25 & \\
\hline & 32 & 2 & 23 & 7 & 43 & 0 & 30 & 2 & 46 & 0 & 34 & \\
\hline & 50 & 0 & 33 & 0 & 46 & 0 & 36 & 0 & 31. & 1 & 13 & \\
\hline & 34 & 0 & 30 & 0 & 38 & 0 & 26 & 4 & $4 ?$ & 0 & 33 & \\
\hline 88 & 40 & 0 & 26 & 1 & 46 & 0 & 32 & 0 & 38 & 1 & 24 & \\
\hline & 38 & J & 25 & 1 & 49 & 0 & 39 & 0 & 41 & 0 & 29 & \\
\hline & 29 & 2 & 13 & 5 & 48 & 0 & 28 & 1 & 39 & 0 & 26 & \\
\hline & 39 & 0 & 28 & 2 & 36 & 1 & 22 & 3 & 42 & 0 & 28 & \\
\hline & 20 & 6 & 10 & 8 & 31 & 2 & 13 & 4 & 35 & 0 & 25 & \\
\hline & 29 & 2 & 17 & 8 & 49 & 0 & 34 & 0 & 40 & 0 & 29 & \\
\hline & 41 & 0 & 26 & 1 & 44 & 0 & 28 & 2 & 34 & 0 & 28 & \\
\hline & 39 & 0 & 29 & 1 & 39 & 0 & 26 & 1 & 52 & 0 & 37 & \\
\hline & 47 & 0 & 36 & 0 & 47 & 0 & 38 & 0 & 55 & 0 & 34 & \\
\hline & 43 & 0 & 32 & 0 & 47 & 0 & 29 & 1 & 43 & 0 & 29 & \\
\hline & 41 & 0 & 26 & 5 & 46 & 0 & 32 & 1 & 27 & 2 & 25 & \\
\hline & 24 & 5 & 20 & 13 & & & & & & & & \\
\hline
\end{tabular}




\section{$\therefore$.}

1872, Dec. 9 to 16 and 22 to 31.

1875, Feb. 4 to 10.

1876, Jan. 12 to 15

1877 , Jan. 1 to 5.

1881 , Jan. 1 to 4 ; Feb. 2 to 7.

1884, Jall. 2 to 10 and 20 to 23

1885, Jan. 17 to 23 .

1886, Jan. 5 to 18 ; Jan. 25 to Feb. 9 ; Dec. 2 to 8. 1887, Jan. 1 to 13 ; Dec. 26 to 31.

1888, Jan. 17 to 30

1892 , Dec. 27 to 31.

1893, Jan. 6 to 25 .

Record of thickness of ice formation as recorded in Weather Bureau Daily Journal by the observer, L. N. Jesunofsky.

1892 , Dec. 27. $\frac{1}{4}$-inch ice formation this a. $\mathrm{m}$.

28. 4 -inch ice formation this a. $m$.

29. 2.-inch ice formation this a. $\mathrm{m}$.

30. Wery thin ice formation this a. $m$.

1893, Jan. 1j. $\frac{1}{10}$-inch ice formation this a. m.

7. $\frac{1}{6}$-inch ice formation this a. $m$.

9. Very thin ice formation this a. $m$.

11. $\frac{1}{10}$-inch ice formation this a. $\mathrm{n1}$.

14. $\frac{8}{10}$-inch ice formation during last night and this $\mathrm{a} . \mathrm{m}$.

16. in -inch ice formation during last nioht and this a. $m$.

17. ${ }^{5}$-inch ice formation during last night and this a.m.

18. ${ }^{4}$-inch ice formation during last night and this $\mathrm{a} . \mathrm{m}$.

18. Snowfall 9:18 a.m. to $3: 08 \mathrm{p} . \mathrm{m}$; total depth, 1.9 inches.

20. $\frac{5}{10}$-inch ieo formation during last night and this a.m.

21. $\frac{5}{10}$-inch ice formation during last night and this $\mathrm{a} . \mathrm{m}$.

22. $\frac{\text { a }}{10}$-inch ice formation during last night and this $\mathbf{a} . \mathbf{m}$.

Nотв.-Observations on thickness of ice made between $7: 45 \mathrm{a} . \mathrm{m}$. and 8:15 a.m. daily.

L. N. JESUNOFSKY, Observer, Weather Bureau. 



THIS BOOK IS DUE ON THE LAST DATE STAMPED BELOW

AN INITIAL FINE OF 25 CENTS WILL BE ASSESSED FOR FAILURE TO RETURN THIS BOOK ON THE DATE DUE. THE PENALTY WILL INCREASE TO 50 CENTS ON THE FOURTH DAY AND TO \$1.00 ON THE SEVENTH DAY OVERDUE.

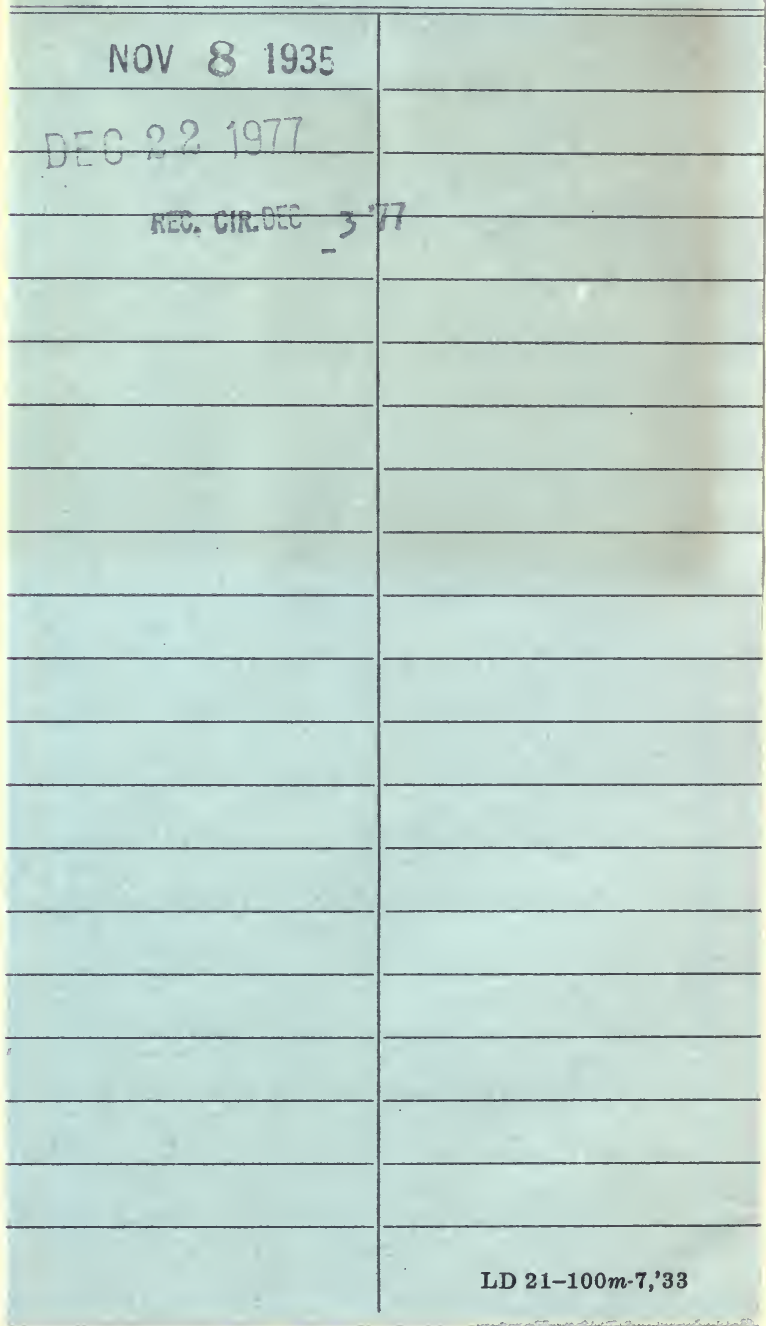




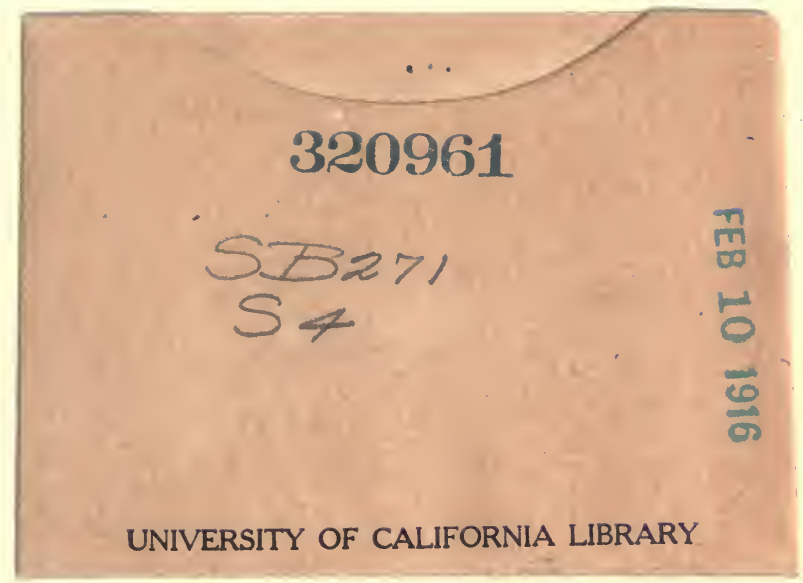


